\title{
Evaluation on the Stability of Slope at Faculty of Engineering and Built Environment (FKAB) using Slope/w
}

\author{
(Penilaian Kestabilan Cerun di Fakulti Kejuruteraan dan Alam Bina (FKAB) \\ Menggunakan Slope/w)
}

Salmah Salween*, Khairul Anuar Mohd Nayan \& Mohammad Omar Faruk Murad

\begin{abstract}
Slope stability topics have become one of the main issues due to the nature of topography and weather conditions in Malaysia. This study examines the stability of the slope at the Faculty of Engineering and Built Environment (FKAB) and eventually to identify the best approach for the analysis. The three main objectives of this study are to evaluate the slope of FKAB using the Limit Equilibrium method, using Slope/w to evaluate the critical soil parameters obtain through back analysis, and eventually to obtain the best method to be use for further analysis on the stability of slope. The steps involve in solving the model of the slope were drawn, defined and assigned accordingly before the final analysis is being carried out in accordance to the methodology of the Slope/w 2007 software. The minimum Factor of Safety (FOS) obtained from the analysis using the unsaturated soil model were found to be 0.999, 1.001 and 1.002 from the Janbu Method, Ordinary Method, Bishop Method and Sarma Method respectively. These Factor of Safety (FOS) were obtained by using back analysis of a two layered model. Layer 1 with soil parameters of $18 \mathrm{kN} / \mathrm{m}^{3}$ of unit weight, $90 \mathrm{kPa}$ of cohesion and $20^{\circ}$ of angle of friction were assigned. Correspondingly for layer 2, the values of $15 \mathrm{kN} / \mathrm{m}^{3}$ unit weight above the groundwater table and $18 \mathrm{kN} / \mathrm{m}^{3}$ below groundwater table, $3 \mathrm{kPa}$ of cohesion and $8^{\circ}$ of angle of friction were assigned. In this study, the Sarma Method was found to be the best method as it satisfies both force and moment equilibrium and is recommended for further analysis to be taken at the slope.
\end{abstract}

Keywords: Slope stability; back analysis; factor of safety; unsaturated soil

ABSTRAK

Isu-isu kestabilan cerun telah menjadi salah satu masalah utama disebabkan sifat topografi dan keadaan cuaca di Malaysia. Kajian ini mengkaji kestabilan cerun di Fakulti Kejuruteraan dan Alam Bina (FKAB) dan seterusnya untuk mengenal pasti kaedah terbaik untuk menganalisis kestabilan cerun. Tiga objektif utama kajian ini adalah untuk menilai kecerunan FKAB melalui kaedah had keseimbangan, menggunakan Slope/w untuk menilai kritikal parameter tanah melalui analisis kembali, dan mendapatkan kaedah yang terbaik untuk digunakan dalam analisis kestabilan cerun. Langkahlangkah yang terlibat dalam menyelesaikan model cerun adalah membentuk, menakrifkan dan mengaplikasikan dengan sewajarnya sebelum menjalani analisis akhir menggunakan Slope/w perisian 2007. Faktor minimum keselamatan (FOS) yang diperoleh daripada analisis menggunakan model tanah tak tepu didapati 0.999, 1.001 dan 1.002 dari Kaedah Janbu, Kaedah Biasa, Kaedah Bishop dan seterusnya Kaedah Sarma. Faktor Keselamatan (FOS) yang telah diperoleh dengan menggunakan analisis kembali berdasarkan model dua lapisan. Lapisan 1 menggunakan $18 \mathrm{kN} / \mathrm{m}^{3}$ unit berat, $90 \mathrm{kPa}$ kejeleketan dan $20^{\circ}$ sudut geseran. Seterusnya bagi lapisan 2, nilai-nilai $15 \mathrm{kN} / \mathrm{m}^{3}$ unit berat di atas aras air tanah dan $18 \mathrm{kN} / \mathrm{m}^{3}$ di bawah aras air tanah, $3 \mathrm{kPa}$ kejeleketan dan $8^{\circ}$ sudut geseran telah digunakan. Dalam kajian ini, didapati bahawa kaedah Sarma merupakan kaedah terbaik bagi analisis kerana ia memenuhi keseimbangan daya dan momen dan dicadangkan untuk analisis kestabilan cerun selanjutnya.

Kata kunci: Kestabilan cerun; analisis kembali; faktor keselamatan; tanah tak tepu

\section{INTRODUCTION}

Slope failure has been acknowledged as one of the most persistent natural catastrophe that can lead to immense loss in property and life. Hence, the analysis of slope stability is very important in order to protect the slopes from failing and minimizing the likelihood of slope failure.
The purpose of this study is to evaluate the slope at FKAB from the Limit Equilibrium method, using Slope/w to evaluate the critical soil parameters obtain through back analysis and eventually to obtain the best method to be use for further analysis of the slope stability. This study has been carried out at one of the slope failure at Faculty 
of Engineering and Built Environment (FKAB), Universiti Kebangsaan Malaysia located in Bangi, Selangor, Malaysia which had occurred along the slope behind the new faculty building.

\section{THEORY}

Limit Equilibirum (LE) methods are based on certain assumptions for the interslice normal (E) and interslice shear ( $\mathrm{T}$ ) forces, and the basic difference among the methods is how these forces are determined or assumed.

In a typical slice of a slope stability analysis, the forces that act on the typical slice are shown in Figure $1 . \mathrm{W}$ is the effective weight of the slice. The forces $N^{\prime}$ and $S^{\prime}$ are the normal and tangential components of the reaction $\mathrm{W}$, respectively. $\mathrm{E}_{1}$ and $\mathrm{E}_{2}$ are the normal forces that act on the sides of the slice. Similarly, the shearing forces that act on the sides of slice are $T_{1}$ and $T_{2}$.

All limit equilibrium methods involves the MohrCoulomb expression to determine the shear strength $\left(\tau_{\mathrm{f}}\right)$ along the sliding surface. The shear stress at which a soil fails in shear is defined as the shear strength of the soil. According to Janbu (1954), a state of limit equilibrium exists when the generalize shear stress $(\tau)$ is expressed as a fraction of the shear strength. At the moment of failure, the shear strength is fully generalized along the failure surface when the critical state conditions are reached.

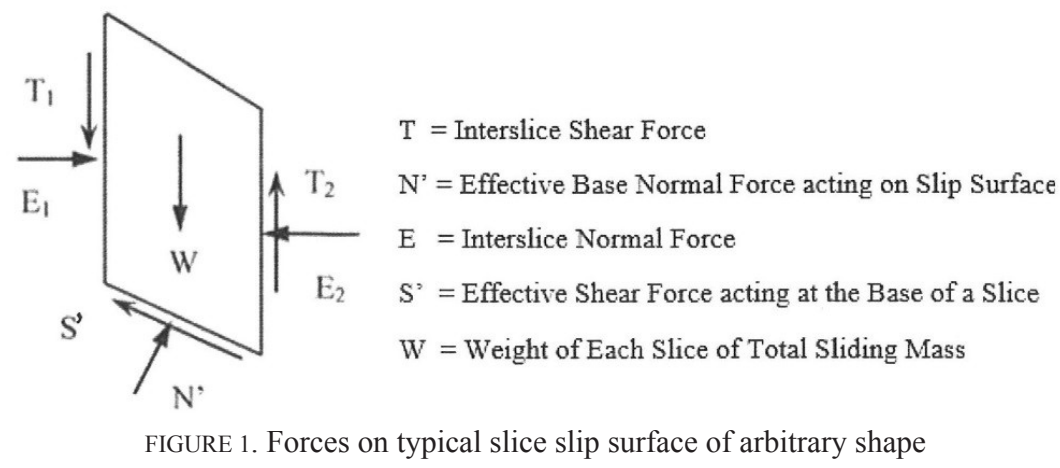

Several limit equilibrium (LE) methods have been developed for slope stability analyses. Fellenius (1936) introduced the first method, referred to as the Ordinary or the Swedish method, for a circular slip surface. Bishop (1955) advanced the first method introducing a new relationship for the base normal force. The equation for the FOS hence became non-linear. At the same time, Janbu developed a simplified method for non-circular failure surfaces, dividing a potential sliding mass into several vertical slices. The generalized procedure of slices (GPS) was developed at the same time as a further development of the simplified method.
Later, Morgenstern-Price (1965), Spencer (1967), Sarma (1973) and several others made further contributions with different assumptions for the interslice forces. A procedure of General Limit Equilibrium (GLE) was developed as an extension of the Spencer (SM) and Morgenstern-Price methods (M-PM), satisfying both moment and force equilibrium conditions (Abramson 2002). These developments are reviewed in the following section, which aims to find out the key differences in the various approaches for FOS determination. A summary of selected LE methods and their assumptions are presented in Tab.

TABLE 1. Summary of LE methods (Abramson 2002, Nash 1987)

\begin{tabular}{lccccl}
\hline Methods & Circular & Non-cir. & $\sum \mathrm{M}=0$ & $\sum \mathrm{F}=0$ & Assumptions for $T$ and $E$ \\
\hline Ordinary & $\sqrt{ }$ & - & $\sqrt{ }$ & - & Neglects both $E$ and $T$ \\
Bishop simplified & $\sqrt{ }$ & $(*)$ & $\sqrt{ }$ & $(* *)$ & Considers $E$, but neglects $T$ \\
Janbu simplified & $(*)$ & $\sqrt{ }$ & - & $\sqrt{ }$ & Considers $E$, but neglects $T$ \\
Janbu GPS & $\sqrt{ }$ & $\sqrt{ }$ & $(* * *)$ & $\sqrt{ }$ & Considers both $E$ and $T$, act at LoT \\
Lowe-Karafiath & - & $\sqrt{ }$ & - & $\sqrt{ }$ & Resultant inclines at, $\theta=1 / 2(\alpha+\beta)$ \\
Coprs of Engrs. & - & $\sqrt{ }$ & - & $\sqrt{ }$ & Resultant inclines at, $\theta=1 / 2\left(\alpha_{1}+\alpha_{2}\right)$ \\
Sarma & $\sqrt{ }$ & $\sqrt{ }$ & $\sqrt{ }$ & $\sqrt{ }$ & Interslice shear, $T=c h+E \tan \varnothing$ \\
Spencer & $\sqrt{ }$ & $(*)$ & $\sqrt{ }$ & $\sqrt{ }$ & Constant inclination, $T=\tan \theta E$ \\
Morgenst.-Price & $\sqrt{ }$ & $\sqrt{ }$ & $\sqrt{ }$ & $\sqrt{ }$ & Defined by $\mathrm{f}(\mathrm{x}), T=f(x) \cdot \lambda \cdot E$ \\
\hline
\end{tabular}

(*) can be used for both circular and non-circular failure surfaces

(**) satisfies vertical force equilibrium for base normal force

$(* * *)$ satisfies moment equilibrium for intermediate thin slices 


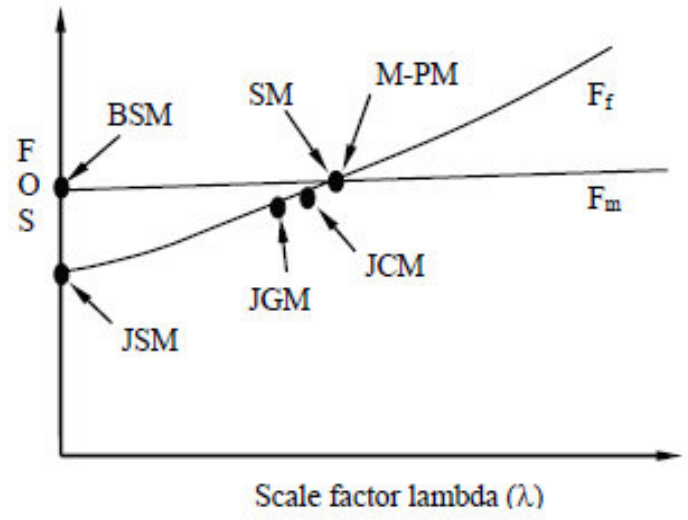

FIGURE 2. Effects on FOS on force and moment equilibrium in relation to lamda $(\lambda)$ (Fredlund and Krahn 1977)

Figure 2 incorporates all the assumptions and development made by the latest LE methods. In fact, this is an extension of Spencer and Morgenstern-Price methods where, the interslice slope, $\tan \theta=\lambda . \mathrm{f}(\mathrm{x})$ is assigned to determine the interslice forces (Krahn 2004, Abramson 2002). This figure is good to compare the most common methods in a FOS versus $\lambda$ diagram as shown in Figure 2. The most likely inclinations of force equilibrium FOS $\left(\mathrm{F}_{\mathrm{f}}\right)$ and moment equilibrium FOS $\left(\mathrm{F}_{\mathrm{m}}\right)$ has been indicated particularly for circular SS analysis. When $\lambda=0$, the FOS is obtained for BSM and JSM, as indicated in Figure 2. Similarly, the intersection point gives the FOS for SM or M-PM. According to Fredlund and Krahn (1977), Janbu's corrected method (JCM) and Janbu's generalised methods (GPS) are close to the intersecting point (see Fig. 2).

Interslice forces depend on a number of factors, including stress-strain and deformation characteristics of the materials. Their evaluation, however, becomes complicated in the LE methods. Therefore, simplified assumptions are made in most methods either to neglect both or to one of them. Nevertheless, the most advanced methods consider these forces in the LE analyses.

The Ordinary Method (OM) is limited to hand calculations and demonstration purposes only, whereas Bishop Simplified (BS) and Janbu Simplified Method (JSM) have been widely used for stability analyses in many years. These methods are common because the Factor of Safety (FOS) in most cases can be calculated with adequate accuracy. However, these methods have limitations in satisfying both force and moment equilibrium.

Interslice force function is defined as the ratio of tangential to normal forces acting on a slice. This function varies according to the assumptions mode. The fundamental difference in the assumptions has been summarized in Table 2. Morgenstern-Price Method assumes an arbitrary function $(f(x))$ with a scale factor $(\lambda)$. Similarly, Janbu's GPS method relates the function to the inclination of the line of thrust. Likewise, Spencer assumed a constant function thought out the sliding surface.
TABLE 2. Interslice forces and relationships (Aryal 2006)

\begin{tabular}{ll}
\hline Morgenst-Price & $T=f(x) \lambda E$ \\
\hline Janbu GPS & $T=E \tan \alpha_{t}-h_{t}(d E / d x)$ \\
Lowe-Karafiath & $T=E \tan \theta$, where $\theta=1 / 2(\alpha+\beta)$ \\
Coprs of Engrs. & $T=E \tan \theta$, where $\theta=1 / 2\left(\alpha_{1}+\alpha_{2}\right)$ \\
Sarma & $T=c h+E \tan \varnothing$ \\
Spencer & $T=E \tan \theta$ \\
\hline
\end{tabular}

However, Sarma (1973) relates the relationship similar to the Mohr-Coulomb expression for shear strength. Moreover, the function in Lowe-Karafiath (1960) method is assumed as a tangent to the average inclination of the slope and sliding plane. However, the Corps of Engineers method considers the function as the average angle of the entry and exit points of the sliding surface.

The strength parameters $\mathrm{c}$ and $\varphi$ can be total strength parameters or effective strength parameters. Slope/w makes no distinction between these two sets of parameters. Which set is appropriate for a particular analysis is project-specific, and is something we as the software user, need to decide. The software cannot do this for us. From a slope stability analysis point of view, effective strength parameters give the most realistic solution, particularly with respect to the position of the critical slip surface.

An analysis of slope stability begins with the hypothesis that the stability of a slope is the result of downward or motivating forces (i.e., gravitational) and resisting (or upward) forces. The resisting forces must be greater than the motivating forces in order for a slope to be stable. The relative stability of a slope (or how stable it is at any given time) is typically conveyed by geotechnical engineers through a factor of safety, FS defined as equation [1];

$$
F S=\frac{\Sigma R}{\Sigma M}
$$

Equation [1] states that the factor of safety (FS) is the ratio between the forces/moments resisting $(\mathrm{R})$ movement and the forces/moments motivating (M) movement. Sarma developed a method for a non-vertical slice or for general blocks. This method satisfies both equilibrium condition. In addition, the interslice force relationship is assumed as a linear Mohr-Coulomb expression. The interslice forces are adjusted until the Factor of Safety for force and moment equilibrium is satisfied. In summary, Sarma's method considers both interslice normal and shear forces and it satisfies both moment and force equilibrium.

Many practical problems involve assessing the shear strength of unsaturated soils. Fredlund and Morgenstern (1977) showed that the shear strength of unsaturated soils can be described by any two of stress state variables, namely, $\left(\sigma_{\mathrm{n}}-\mathrm{u}_{\mathrm{a}}\right)$ and $\left(\mathrm{u}_{\mathrm{a}}-\mathrm{u}_{\mathrm{w}}\right)$, where $\mathrm{u}_{\mathrm{a}}$ is the pore-air pressure. Fredlund (1987) proposed the following equation [2] for the strength of unsaturated soil; 


$$
\tau=\mathrm{c}^{\prime}+\left(\sigma_{\mathrm{n}}-\mathrm{u}_{\mathrm{a}}\right) \tan \phi^{\prime}+\left(\mathrm{u}_{\mathrm{a}}-\mathrm{u}_{\mathrm{w}}\right) \tan \phi^{\mathrm{b}}
$$

(2) it is assigned with that failure of the slip circle to follow from left to right path. The Sarma analysis and half-sine function were selected and the software also gives the result of the factor of safety for the Ordinary, Bishop and Janbu method of analysis.

After the material input and pore pressure were assigned, the probable slip surface for the circular failure using the grid and radius method was selected for the analysis. When the slip surface has been specified, then Slope/w runs several checks to verify the input data using the verify/optimize data command in the Tools menu.

When the verification is completed and there are no errors, then Slope/w computes the factor of safety using the method of slice selected. The minimum factor of safety is obtained for that particular analysis and its corresponding critical slip surface is displayed.

One of the problems with this method is how to locate the critical slip surface. This difficulty is solved by attempting multiple trials until we have obtained a satisfied value of overall minimum Factor of Safety of about unity. the Slope/w program. The analysis type is then selected and
The geometry was created in gsz format and imported in

The process in the Slope/w Analysis is briefly explained and summarized as shown in Figure 3.

A limit equilibrium analysis was carried out using the Slope/w software for the slope stability of the natural slope.

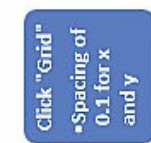

1

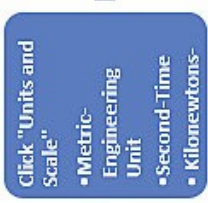

金

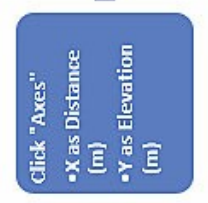

1
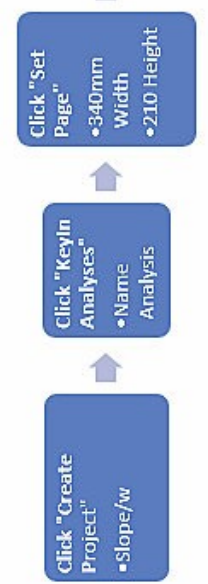

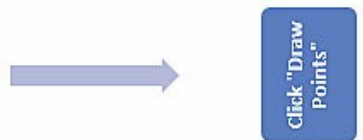

(1)
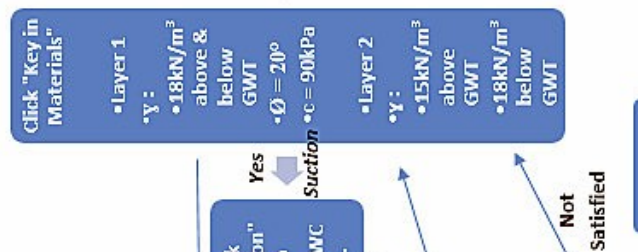

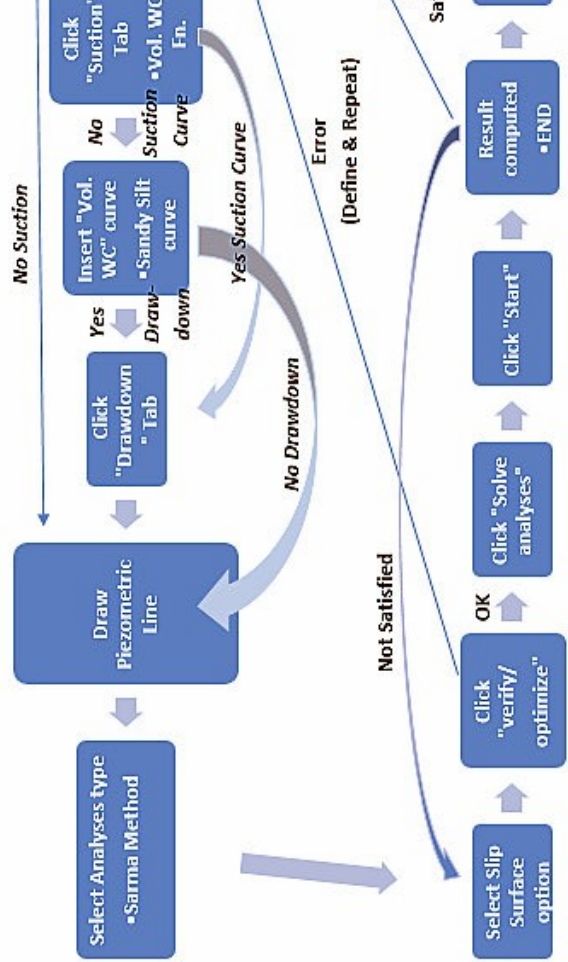

FIGURE 3. Flowchart in applying Slope/w 


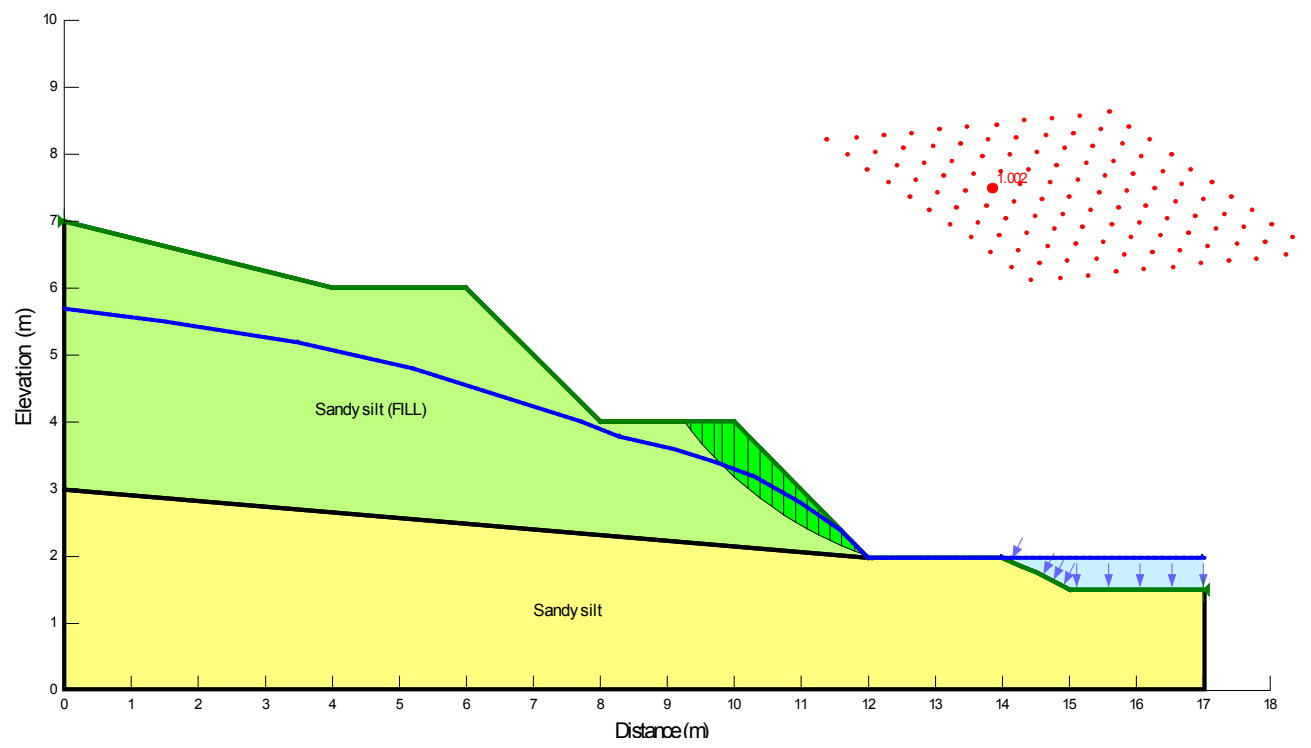

FIGURE 4. Output computed with the minimum FOS (Slope/w 2007)

RESULTS \& DISCUSSION

Figure 4 shows the circular slip surface with the overall minimum factor of safety of 1.002 from the Sarma Method in Slope/w. Since the minimum value is inside the Grid, this is often use as a guide to indicate that the minimum factor of safety has been found.

In order to identify the critical slip surface, the smallest Factor of Safety is to be taken from several try and error from the analysis. Table 3 summarizes all the FOS that have been obtained with 1.001 for Ordinary method, 1.002 for Bishop method, 0.999 for Janbu method and 1.002 for Sarma method. If each method gives very nearly the same critical slip surface, then this is a good indication that the true critical circular slip surface has been located.The summary of the back analysis parameters used to calculate the critical slip surface for the soil layers above and below the water table in terms of unit weight, angle of friction and cohesion are summarized for the purpose of evaluation as shown in Table 4.

Table 5 compares the result of various studies from different sites on residual soil with the results obtained from this study using back analysis of a two layered model. Layer 1 with soil parameters of $18 \mathrm{kN} / \mathrm{m}^{3}$ of unit weight, 90 $\mathrm{kPa}$ of cohesion and $20^{\circ}$ of angle of friction were assigned. Correspondingly for layer 2, the values of $15 \mathrm{kN} / \mathrm{m}^{3}$ unit weight above the groundwater table and $18 \mathrm{kN} / \mathrm{m}^{3}$ below groundwater table, $3 \mathrm{kPa}$ of cohesion and $8^{\circ}$ of angle of friction were assigned.

TABLE 3. Summary on the minimum FOS values from this study

\begin{tabular}{lcc}
\hline & \multicolumn{2}{c}{ Minimum Factor of Safety (FOS) } \\
\cline { 2 - 3 } Limit Equilibrium (LE) Method & Moment & Force \\
\hline Odinary & 1.001 & \\
Bishop & 1.002 & 0.999 \\
Janbu & & 1.002 \\
Sarma & 1.002 & \\
\hline
\end{tabular}

TABLE 4. Critical Soil Parameters used from back analysis

\begin{tabular}{|c|c|c|c|c|}
\hline \multirow{2}{*}{$\begin{array}{l}\text { Layers based on the groundwater } \\
\text { table (GWT) }\end{array}$} & \multicolumn{2}{|c|}{ Unit weight, $\mathrm{kN} / \mathrm{m}^{3}$} & \multirow{2}{*}{ Angle of friction, $\left(^{\circ}\right)$} & \multirow{2}{*}{$\begin{array}{l}\text { Cohesion } \\
(\mathrm{kPa})\end{array}$} \\
\hline & Above & Below & & \\
\hline Layer 1 - Sandy Silt & 18 & 18 & 20 & 90 \\
\hline Layer 2 - Sandy Silt (FILL) & 15 & 18 & 8 & 3 \\
\hline
\end{tabular}


TABLE 5. Comparison of residual soil strength parameters at various sites

\begin{tabular}{|c|c|c|c|c|c|c|c|c|c|c|}
\hline \multirow{4}{*}{ Source } & \multirow{4}{*}{ Location } & \multirow{4}{*}{$\begin{array}{l}\text { Depth } \\
\text { (m) }\end{array}$} & \multicolumn{8}{|c|}{ Triaxial Test } \\
\hline & & & \multirow{2}{*}{\multicolumn{2}{|c|}{$\begin{array}{l}\text { Unconsolidated } \\
\text { Undrained }\end{array}$}} & \multirow{2}{*}{\multicolumn{2}{|c|}{$\begin{array}{l}\text { Consolidated } \\
\text { Undrained }\end{array}$}} & \multicolumn{4}{|c|}{ Back Analysis } \\
\hline & & & & & & & \multicolumn{2}{|c|}{ Layer 1} & \multicolumn{2}{|c|}{ Layer 2} \\
\hline & & & $\begin{array}{c}\mathrm{C} \\
\left(\mathrm{kN} / \mathrm{m}^{3}\right)\end{array}$ & $\begin{array}{c}\phi \\
\left({ }^{\circ}\right)\end{array}$ & $\begin{array}{c}\mathrm{C} \\
\left(\mathrm{kN} / \mathrm{m}^{3}\right)\end{array}$ & $\begin{array}{l}\phi \\
\left({ }^{\circ}\right)\end{array}$ & $\begin{array}{c}\mathrm{C} \\
\left(\mathrm{kN} / \mathrm{m}^{3}\right)\end{array}$ & $\begin{array}{c}\phi \\
\left({ }^{\circ}\right)\end{array}$ & $\begin{array}{c}\mathrm{C} \\
\left(\mathrm{kN} / \mathrm{m}^{3}\right)\end{array}$ & $\begin{array}{l}\phi \\
\left(0^{\circ}\right.\end{array}$ \\
\hline Kepli (1994) & Melaka & & $10-33$ & & & & & & & \\
\hline Todo et al (1994) & Kuala Lumpur & & $25-180$ & & & & & & & \\
\hline Ramli (1991) & $\begin{array}{l}\text { Sungai Buluh, Jalan } \\
\text { Duta Damansara, } \\
\text { Bukit Lanjan, Tapah } \\
\text { dan Skudai }\end{array}$ & & & & $0-40$ & $14-36$ & & & & \\
\hline $\begin{array}{l}\text { Todo \& Pauzi } \\
\text { (1989) }\end{array}$ & Malaysia \& Singapura & 15 & $27-87$ & $<11$ & & & & & & \\
\hline $\begin{array}{l}\text { Balasubramaniam, } \\
\text { et al. (1985) }\end{array}$ & Malaysia & & $73-117$ & $1-9.5$ & & & & & & \\
\hline Ting \& Ooi (1976) & Malaysia & $5-21$ & $\begin{array}{l}61.8- \\
117\end{array}$ & $1-9.5$ & & & & & & \\
\hline Lee (1967) & Cameron Highland & $0.85-10$ & & & $1-5$ & $25-35$ & & & & \\
\hline Rahardjo (2002) & $\begin{array}{l}\text { Yishun, Singapura } \\
\text { Mandai, Singapura }\end{array}$ & $\begin{array}{l}4.5-19 \\
1.5-28\end{array}$ & & & $6-50$ & $28-33$ & & & & \\
\hline Winn, et al. & $\begin{array}{c}\text { Bukit Timah, } \\
\text { Singapura }\end{array}$ & & $10-150$ & $<10$ & & $20-40$ & & & & \\
\hline UKM (This study) & Bangi, Malaysia & & & & & & 90 & 20 & 3 & 8 \\
\hline
\end{tabular}

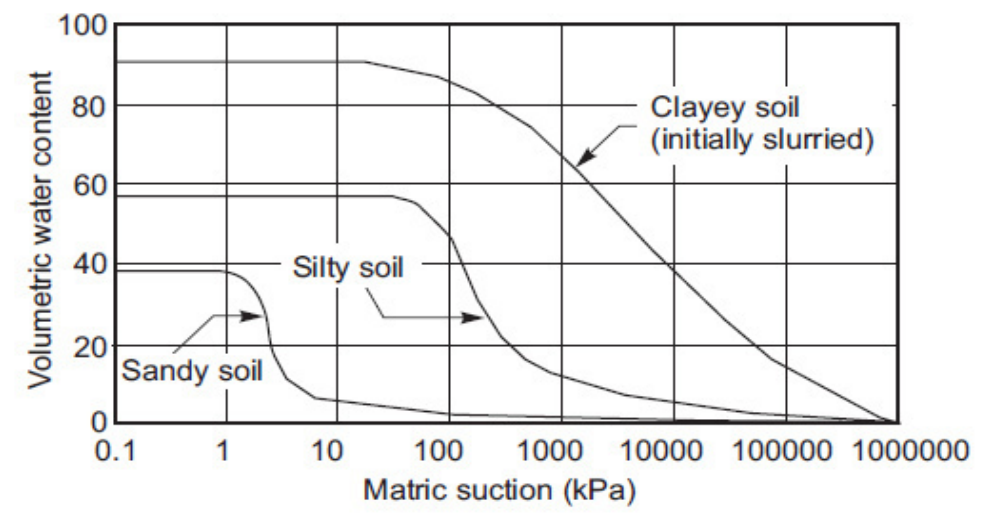

FIGURE 5. Soil-water characteristic curves for sandy soil, a silty soil, and a clayey soil (Delwyn \& Fredlund 2011)

From the preliminary report with the borelog profile given of the slope based on Figure 5, evaluation has been made to produce the Volumetric Water Content Versus Matric Suction Curve applied in the slope stability model shown in Figure 6.
From the result of the slope stability analysis of Slice 1 as shown in Figure 7, the base shear mobile force to be $0.43989 \mathrm{kPa}$ that has been obtained in comparison to the value of $0.52633 \mathrm{kPa}$ as computed using conventional formula of equation [2]. The difference that occurred in the study can be attributed to the many combinations of inputs that were used when running the software. Nevertheless, the difference obtained is relatively small. 


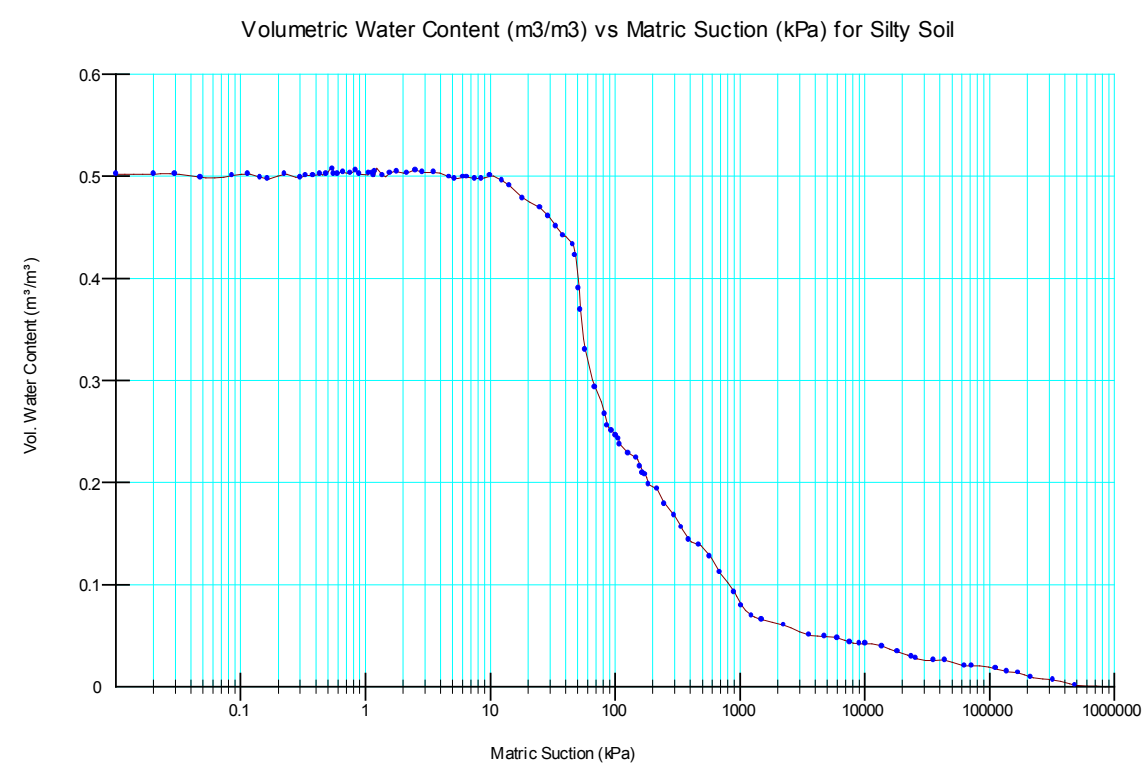

FIGURE 6. Volumetric water content $\left(\mathrm{m}^{3} / \mathrm{m}^{3}\right)$ versus matric suction $(\mathrm{kPa})$ for silty soil applied in the slope stability model
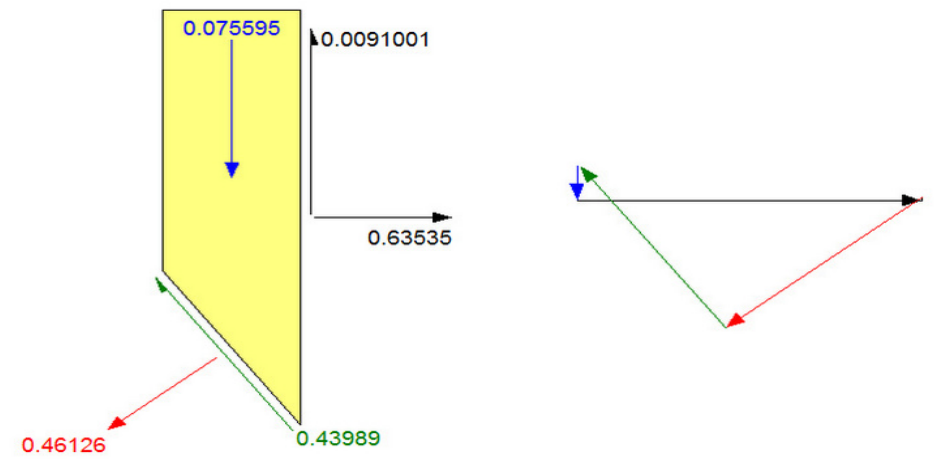

FIGURE 7. Output from the computed slice (Slope/w 2007)

\section{CONCLUSION}

The overall minimum Factor of Safety (FOS) of 1.002 that has been obtained from the Sarma Method which indicates that the slope is in a critical condition. The analysis to evaluate the slope failure in FKAB using Limit Equilibrium (LE) Method with Slope/w is best obtained from the Sarma Method as it satisfies all equilibrium conditions of both force and moment. The result from this method is in agreement with the result that was obtained from the methods of Ordinary, Bishop and Janbu. For layer 1, critical soil parameters of $18 \mathrm{kN} / \mathrm{m}^{3}$ of unit weight, $90 \mathrm{kPa}$ of cohesion and $20^{\circ}$ of angle of friction have been obtained. Correspondingly for layer 2, values of $15 \mathrm{kN} / \mathrm{m}^{3}$ for the unit weight above the groundwater table and $18 \mathrm{kN} / \mathrm{m}^{3}$ below the groundwater table were obtained with corresponding values of $8^{\circ}$ angle of friction and $3 \mathrm{kPa}$ of cohesion.
REFERENCES

Abramson, L.W. 2002. Slope Stability and Stabilization Methods : General Slope Stability Concepts. John Wiley \& Sons, Inc.

Aryal, K. 2006. A Study On Interslice Force Function And Line Of Thrurst In Slope Stability Analysis.

Bishop, A.W. 1955. The use of slip circles in stability analysis of slopes. Geotechnique 5 (1): 7-17.

Delwyn G. \& Fredlund, D. S. 2011. Estimation of soil suction from the soil-water. Can. Geotech. J. 48: 186198.

Fellunius, W. 1936. Calculations of the Stability of Earth Dams. Proceedings of the Second Congress of Large Dams. 4: 445-63, Washington D.C.

Fredlund, D. G. 1987. Slope Stability Analysis Incorporating the Effect of Soil Suction. Slope Stability, Chapter 4 M. G. Andersen and K. S. Richards, Eds. New york: Wiley, pp. 113-44. 
Fredlund, D. G. \& Krahn, J. 1977. Comparison of slope stability methods of analysis. Canadian Geotechnical Journal 14: 429-39.

Fredlund, D. G. \& N.R. Morgenstern. 1977. Stress state variables for unsaturated soils. ASCE J. Geotech. Eng. Div. 103: 447-466.

GEO-SLOPE International Ltd. 2009. Slope Stability Modeling with SLOPE/W 2007. Calgary, Alberta, Canada.

Janbu, N. 1954. Stability analysis of Slopes with Dimensionless Parameters. Thesis for the Doctor of Science in the Field of Civil Engineering, Harvard University Soil Mechanics Series, (No. 46).

Krahn, J. 2004. Stability Modelling with Slope/W and Engineering Methodology. $1^{\text {st }}$ edition. Geo-Slope/W International, Ltd.

Lowe, J. \& Karafiath, R. V. 1960. Stability of Earth Dam upon Drawdown. Proceedings of the first Pan America Conference on Soil Mechanics and Foundation Engineering, Maxico City, pp. 537-52.

Morgenstern, N. R. \& Price, V. E. 1965. The analysis of the stability of general slip surfaces. Geotechnique 15(1): 77-93.
Nash, D. 1987. Comprehensive Review Limit Equilibrium Methods of Stability Analysis. Slope Stability, Chapter 2. M.G. Andersen and K. S. Richards, Eds. New York: Wiley, 11-75.

Sarma, S. K. 1973. Stability analysis of embankment and slopes. Geotechnique 23 (3): 423-33.

Spencer, E. 1967. A method of analysis of the stability of embankments, assuming parallel interslice forces. Geotechnique 17: 11-26.

Salmah Salween*

Khairul Anuar Mohd Nayan

Mohammad Omar Faruk Murad

Department of Civil and Structural Engineering

National University of Malaysia,

43600 UKM, Bangi Selangor,

Malaysia.

*Corresponding author; email:

salmah_salween@hotmail.com

Received Date: $14^{\text {th }}$ April 2015

Accepted Date: $15^{\text {th }}$ October 2015 